\title{
Temporal changes in tree community structure and richness in a seasonally dry tropical forest in Minas Gerais, southeastern Brazil
}

\author{
Cambios temporales en la estructura y riqueza de la comunidad arbórea \\ en un bosque tropical estacionalmente seco en Minas Gerais, sudeste de Brasil
}

\author{
Paola F Santos a, Paulo O Garcia a, Rubens M Santos a, Jean D Morel a, \\ Matheus H M Benício a , Deborah M G Apgaua ${ }^{\mathrm{a}, \mathrm{b} *}$, David Y P Tng ${ }^{\mathrm{a}, \mathrm{b}}$ \\ *Corresponding author: ${ }^{a}$ Federal University of Lavras, Department of Forest Sciences, \\ Lavras 37200-000, Brazil, deborah.ufla@gmail.com \\ b James Cook University, Centre for Tropical, Environmental, and Sustainability Sciences, \\ College of Marine and Environmental Sciences, Australia.
}

\begin{abstract}
SUMMARY
Seasonally Dry Tropical Forests (SDTF) are gaining recognition as a habitat of global conservation significance. However, these forests often occur on rich soils, and are therefore prone to disturbance by agricultural activities. Across their range, many SDTFs are in various stages of regeneration, although little is known about their regeneration dynamics and temporal change in general. To fill this knowledge gap, we studied the changes in species diversity and community structure of an SDTF tree community with a history of past selective logging located in northern Minas Gerais, Brazil. We hypothesized an increase in species diversity and biomass-related parameters, along with a reduction in stem density for the community after five years of regeneration. In 2005, we measured all trees (diameter $\geq 3.18 \mathrm{~cm}$ at $1.3 \mathrm{~m}$ ) within twenty $20 \times 20 \mathrm{~m}\left(400 \mathrm{~m}^{2}\right)$ plots in the patch, and we remeasured the trees in 2010 . Between the two censuses, we found no significant changes in species richness and diversity, suggesting that species accumulation had leveled out. However, we found significant gains in tree basal area and recruitment, suggesting continual regeneration. Diameter class distributions of the five most abundant tree species showed similar patterns. We conclude that past disturbances can have ongoing effects on SDTF vegetation, although inter-annual variations may also play a regulatory role on community dynamics.
\end{abstract}

Key words: forest ecology, ecosystems dynamics, forest regeneration, remnant vegetation, tropical tree diversity.

\section{RESUMEN}

Los Bosques Tropicales Secos Estacionales (BTSE) gozan de reconocimiento como hábitat de importancia global para la conservación. Sin embargo, estos bosques se encuentran a menudo en suelos ricos, y, por lo tanto, son propensos a perturbación por actividades agrícolas. En su rango de distribución, muchos BTSE están en varias etapas de regeneración, pero se sabe poco acerca de su dinámica de regeneración y cambio temporal en general. Para llenar este vacío de conocimiento, se estudiaron cambios en la diversidad de especies y la estructura de una comunidad de árboles de un BTSE con una historia de tala selectiva en el norte de Minas Gerais, Brasil. Se hipotetizó un aumento en la diversidad de especies y parámetros relacionados con la biomasa, junto con una reducción de la densidad para la comunidad después de cinco años de regeneración. En 2005, todos los árboles (diámetro $\geq 3,18 \mathrm{~cm}$ a 1,3 $\mathrm{m}$ ) fueron medidos dentro de veinte parcelas de 20x20 m $\left(400 \mathrm{~m}^{2}\right)$, y fue repetido el mismo procedimiento en 2010 . Entre ambos censos, no hubo cambios significativos en riqueza de especies ni diversidad, lo que sugiere que la acumulación de especies se había estabilizado. Sin embargo, hubo ganancias significativas en área basal y en el reclutamiento, lo que sugiere una regeneración continua. Las distribuciones diamétricas de las cinco especies de árboles más abundantes mostraron patrones similares. Se concluyó que los disturbios pasados pueden tener efectos continuos sobre la vegetación del BTSE, aunque las variaciones interanuales también pueden desempeñar un papel regulador en la dinámica de la comunidad.

Palabras clave: ecología de bosque, dinámica de ecosistemas, regeneración de bosques, vegetación remanente, diversidad de árboles tropicales.

\section{INTRODUCTION}

Seasonally dry tropical forests (STDFs) are increasingly being recognized for their global presence, ecological diversity, and socio-economic significance (de Albuquerque et al. 2012). At the same time, these ecosystems are considered among the most threatened in the world (Apgaua et al. 2014b). In South America for example, the 
principal threat to STDFs is agricultural activities, because areas where SDTF occurs have fertile soils, and are typically cultivated intensively for a number of years and subsequently abandoned due to reduced productivity. This has led to fragmentation of SDTF in many areas and to a growing extent of SDTFs in a state of regeneration or succession (Chazdon 2003, Coelho et al. 2016).

The process of forest regeneration typically involves changes in floristics and structural dynamics (Chazdon 2003, Coelho et al. 2016). An area with post-disturbance tree regeneration is characterized by high stem abundance and basal area turnover rates, followed by a reduction in the number of individuals and increased biomass at late successional stages (Werneck and Franceschinelli 2004, Machado and Oliveira-Filho 2010). However, anthropogenic activities can affect these natural processes and thereby influence forest successional trajectories, resulting in very different ecosystems from those that previously existed (Lebrija-Trejos et al. 2010).

Studies on natural regeneration in Neotropical STDFs have been conducted variously in Mexico (Lebrija-Trejos et al. 2010), Nicaragua (Marín et al. 2005) and Brazil (Werneck and Franceschinelli 2004). However, there have been comparatively little studies for the Caatinga domain (de Albuquerque et al. 2012), an important phytogeographical region of SDTF vegetation in Brazil.

In northern areas of Minas Gerais State, Brazil, SDTF vegetation occurs in an ecotonal region wedged between savanna and rainforest (Apgaua et al. 2014b). Here, the integrity of SDTFs is threatened by agricultural expansion, mining activities and timber extraction (Santos et al. 2011). Long-term monitoring of tree communities in this region is therefore urgently needed to provide an improved understanding of the floristic and structural patterns of SDTFs, and to underpin their conservation and management.

We aimed at filling this gap of knowledge regarding SDTF forest dynamics by investigating the demographic and structural changes of the tree component in an SDTF community located in southeast Brazil, five years after an initial vegetation description in the area in 2005 (Santos et al. 2012). Following known patterns of SDTF vegetation succession (Lebrija-Trejos et al. 2010, Coelho et al. 2016), we hypothesized an increase in tree biomass, richness and diversity, along with a reduction in stem density for the community. Based on tree diameter class patterns observed in other studies (e.g. Apgaua et al. 2014a, Coelho et al. 2016) for late successional SDTF forest, we also predicted that there would be higher recruitment and mortality rates for trees in the smaller size class diameters, and a higher gain in biomass in intermediate classes.

\section{METHODS}

Study site. The study was conducted in a $\sim 80$ ha remnant of seasonally dry tropical forest (SDTF) located at Vale

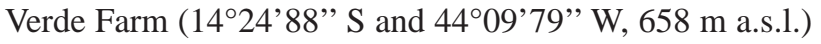

in the municipality of Juvenília, northern Minas Gerais, Brazil. The SDTF in the area has a seasonally deciduous tree component with discontinuous canopy which varied in both height (3-9 m) and density (Santos et al. 2012, Apgaua et al. 2014a). The flora comprises mostly succulent cacti and non-succulent shrubs and trees, many of which are armed with either thorns or prickles and bear microphyllous foliage, though they are leafless during periods of drought (Santos et al. 2012).

Interviews with the farm owners and local inhabitants in the area revealed that parts of the area were selectively logged 40 years ago for commercially valuable species of trees including Handroanthus ochraceus, Myracrodruon urundeuva and others. However, some individual trees in specific sections of the forest were preserved. Currently, trampling by livestock is the main source of disturbance to the forest fragment, and the adjacent areas are composed of pastures and abandoned fields undergoing natural regeneration (Santos et al. 2011).

The terrain is slightly hilly with gentle slopes in limestone outcrop areas. This area occurs in a region with most part of annual rainfall occurring in the summer. Annual average temperature exceeds $20{ }^{\circ} \mathrm{C}$ and annual average rainfall is $1,000 \mathrm{~mm}$ with the rainy season occurring between November and January (Santos et al. 2011). Soil at our sampling sites includes eutrophic red-yellow argisols and eutrophic red nitosols.

Sampling. We surveyed the tree community of the site initially in 2005 (Santos et al. 2011) and subsequently in 2010. We used twenty $20 \times 20 \mathrm{~m}\left(400 \mathrm{~m}^{2}\right)$ sampling plots distributed along a transect within and parallel to the widest edge of the forest fragment (sampling area totaling $8,000 \mathrm{~m}^{2}$ ). The plots were arranged $10 \mathrm{~m}$ apart from each other along the transect. This amounted to a total sampling area of 0.8 ha of SDTF. All living trees with a diameter at breast height (DBH or $1.3 \mathrm{~m}$ height) $\geq 3.18 \mathrm{~cm}$ were tagged with numbered aluminum tags, identified at the species level, and had their DBH and height measured. During the second survey, in January 2010, the DBH of all surviving individuals was remeasured, the number of dead individuals was determined and the individuals (recruits) that reached a $\mathrm{DBH} \geq 3.18 \mathrm{~cm}$ (new recruits) were identified, tagged and measured.

To analyze the changes in species richness and diversity (Shannon diversity index) of the trees between 2005 and 2010 surveys, we computed species accumulation curves using EstimateS 8.2 software (Colwell 2013). Curves were generated using 999 randomizations of sampling units and means and standard deviations were used for comparisons. To determine the evenness of the vegetation, we also calculated Pielou's evenness indices (Kent 2011).

Tree community structure and population dynamics. Tree community structure of the SDTF community was visualized by plotting bar plots showing the size class distribu- 
tions of the overall tree community and the top five most representative and abundant species (henceforth "important species"). The selection of the five important species was based on their importance value (IV) in both surveys - an index that accounts for species density, dominance and cover (Kent 2011). We classified stem sizes into eight equal DBH classes of $6 \mathrm{~cm}$ intervals each: $3 \leq \mathrm{DBH}_{1}<9$; $9 \leq \mathrm{DBH}_{2}<15,15 \leq \mathrm{DBH}_{3}<21,21 \leq \mathrm{DBH}_{4}<27$, $27 \leq \mathrm{DBH}_{5}<33,33 \leq \mathrm{DBH}_{6}<39,39 \leq \mathrm{DBH}_{7}<45$ and $\mathrm{DBH}_{8}>45 \mathrm{~cm}$.

Population dynamics and the changes in tree community structure were determined in terms of annual recruitment and mortality rates of individuals (demographic parameters) and annual basal area increment and loss rates (biomass-related parameters). Dynamics parameters were calculated for the total sample and for each diameter class according to exponential formulas by Sheil and May (1996). The rate and direction of structural changes were determined by analyzing turnover rates and net changes in the number of individuals and basal area - BA (sensu Korning and Balslev 1994).

We, therefore, used the following formulas to calculate parameters of mortality $(M)$, recruitment $(R)$, basal area loss (L), basal area increment (G), turnover in abundance (TN) and basal area (TBA), and net changes in abundance $(\triangle \mathrm{N})$ and basal area $(\triangle \mathrm{BA})$ :

$$
\begin{gathered}
\mathrm{M}=\left\{1-\left[\left(\mathrm{N}_{0}-\mathrm{m}\right) / \mathrm{N}_{0}\right]^{1 / t}\right\} \times 100 \\
\mathrm{R}=\left[1-\left(1-\mathrm{r} / \mathrm{N}_{\mathrm{t}}\right)^{1 / \mathrm{t}}\right] \times 100 \\
\mathrm{~L}=\left\{1-\left[\left(\mathrm{BA}_{0}-\left(\mathrm{BA}_{\mathrm{m}}+\mathrm{BA}_{\mathrm{d}}\right) / \mathrm{BA}_{0}\right]^{1 / t}\right\} \times 100\right. \\
\mathrm{G}=\left\{1-\left[1-\left(\mathrm{BA}_{\mathrm{r}}+\mathrm{BA}_{\mathrm{g}}\right) / \mathrm{BA}_{\mathrm{t}}\right]^{1 / t}\right\} \times 100 \\
\mathrm{TN}=(\mathrm{M}+\mathrm{R}) / 2 \\
\mathrm{TBA}=(\mathrm{P}+\mathrm{G}) / 2 \\
\Delta \mathrm{N}=\left[\left(\mathrm{N}_{\mathrm{t}} / \mathrm{N}_{0}\right)^{1 / \mathrm{t}}-1\right] \times 100 \\
\Delta \mathrm{BA}=\left[\left(\mathrm{BA}_{\mathrm{i}} / \mathrm{BA}_{0}\right)^{1 / \mathrm{t}}-1\right] \times 100
\end{gathered}
$$

In the formulas, $\mathrm{t}$ corresponds to the time between surveys; $\mathrm{N}_{0}$ and $\mathrm{N}_{\mathrm{t}}$ correspond to the initial and final number of trees; $\mathrm{m}$ and $\mathrm{r}$ are the number of dead trees that were alive in the first measurement, though not in the second, and new recruits that reach the minimum size class diameter and therefore were included in the survey, respectively. Lastly, BA refers to basal area in the $2005\left(\mathrm{BA}_{\mathrm{c}}\right.$ ) and 2010 $\left(\mathrm{BA}_{\mathrm{t}}\right)$ surveys, of dead $\left(\mathrm{BA}_{\mathrm{m}}\right)$ and recruited $\left(\mathrm{BA}_{\mathrm{r}}\right)$ individuals, and of individuals with basal area decrease $\left(\mathrm{BA}_{\mathrm{d}}\right)$ and gain $\left(\mathrm{BA}_{\mathrm{g}}\right)$. To determine possible structural changes between surveys, we compared the values found in 2005 and 2010 using a $G$ test (Zar 2010).

\section{RESULTS}

Species richness and diversity indices. In 2005, we recorded 1,321 tree individuals in our vegetation survey, consisting of 67 species within 19 families (Santos et al. 2012). Species richness in individual plots ranged between 12-25 species. In 2010, we observed $3.1 \%$ increase in stem abundance (1,363 individuals) and reduction in species richness (65 species) across our plots. Eighteen species were represented by single individuals, and these constituted over $25 \%$ of the species richness of the tree community in 2005. Meanwhile, four of these species were not recorded in 2010 due to mortality of individuals of the species Bauhinia cheilantha (Bong.) Steud., Cnidoscolus oligandrus (Müll.Arg.) Pax, Jatropha mollissima (Pohl) Baill., and Senna spectabilis (DC.) H.S. Irwin et Barneby. However, two new species Bauhinia catingae Harms and Terminalia fagifolia Mart. were included in the survey in 2010. Species represented by two or more individuals were all present in the 2010 survey.

There were no conspicuous differences in species richness (figure 1A), Shannon diversity index (figure 1B), or Pielou's evenness index (not plotted) between the two sampling periods (table 1).
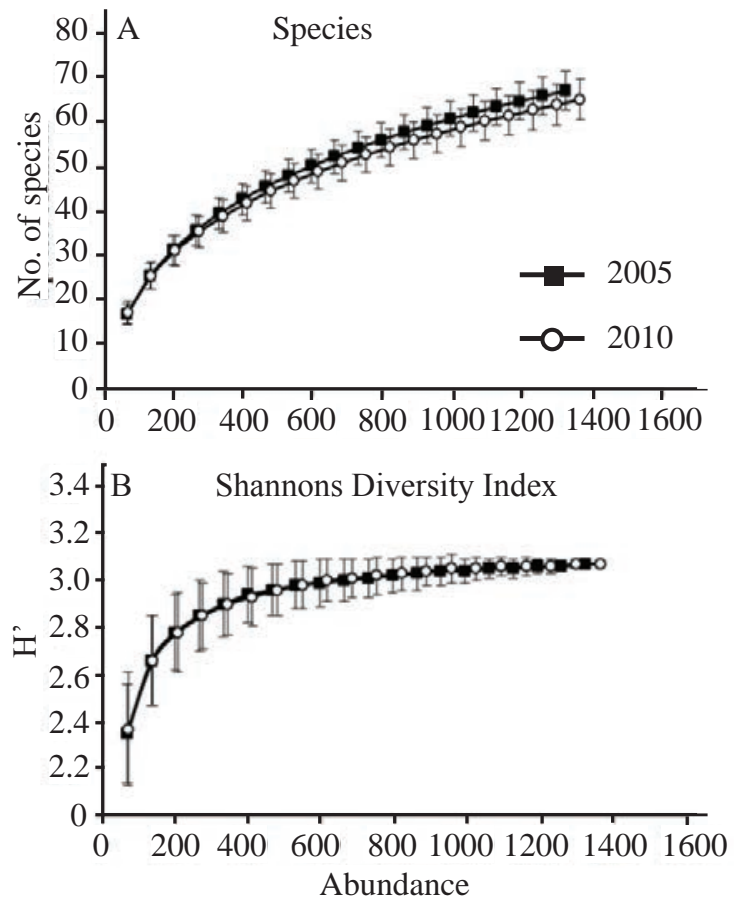

Figure 1. Species accumulation curves for (A) species richness and (B) Shannon diversity index (H') in a seasonally dry tropical forest tree community at Vale Verde farm, Juvenília, Minas Gerais, southeast Brazil in 2005 and 2010.

Curvas de acumulación de especies para (A) riqueza de especies y (B) índice de diversidad de Shannon (H') en una comunidad de bosques tropicales estacionalmente secos en la granja Vale Verde, Juvenília, Minas Gerais, sudeste de Brasil en 2005 y 2010. 
Table 1. Vegetation parameters of a seasonally dry tropical forest tree community in a long-term study in Minas Gerais, southeast Brazil in 2005 and 2010. Standard deviations are indicated where applicable and different alphabets indicate significant differences between years based on G-tests (Zar 2010) at $\alpha=0.05$.

Parámetros de vegetación de una comunidad de bosques tropicales estacionalmente secos en un estudio a largo plazo en Minas Gerais, sudeste de Brasil en 2005 y 2010. Las desviaciones estándar son indicadas donde sea aplicable y diferentes alfabetos indican diferencias significativas entre años basados en pruebas $\mathrm{G}$ (Zar 2010) en $\alpha=0,05$.

\begin{tabular}{lcc}
\hline Vegetation parameter & 2005 & 2010 \\
\hline Overall species richness & 67 & 65 \\
Overall Shannon's diversity index & $3.06^{\mathrm{a}}$ & $3.07^{\mathrm{a}}$ \\
Overall Pielou's Evenness index & $0.73^{\mathrm{a}}$ & $0.73^{\mathrm{a}}$ \\
Total no. of stems & 1321 & 1363 \\
Mean no. of Stems $\left(\mathrm{plot}^{-1}\right)$ & $66.1( \pm 20.52)$ & $68.25( \pm 21.19)$ \\
Total basal area $\left(\mathrm{m}^{2} \mathrm{ha}^{-1}\right)$ & 16.49 & 18.34 \\
Basal area $\left(\mathrm{m}^{2} \mathrm{plot}^{-1}\right)$ & $0.66^{\mathrm{a}}( \pm 0.16)$ & $0.73^{\mathrm{b}}( \pm 0.17)$ \\
\hline
\end{tabular}

Tree community structure and population dynamics. Across the two surveys, the tree diameter distribution of the overall community did not show very large differences. The tree community represented in the total sample showed a reduction in abundance only in the first diameter class, and there was a slightly higher abundance of stems in the second diameter class $\left(6 \leq \mathrm{DBH}_{2}<12 \mathrm{~cm}\right.$; figure $2 \mathrm{~A}$ ). In addition, over $80 \%$ of individuals remained in their size class, except for the first diameter class, in which only $63.9 \%$ of original individuals remained in the class.

Annual recruitment in the tree community was higher than mortality, with 123 and 81 tree individuals recruited and dead respectively in 2010 . This resulted in a positive net increase in the number of individuals in the community (tables 1, 2). The percentage of surviving individuals in 2010 was $90.97 \%$, whereas annual turnover rate was 1.57 $\%$. The monitoring of tree community structure and composition showed faster basal area turnover rates, mainly due to high gain rates (table 2 ). Annual gain (3.79 \% year ${ }^{-1}$ ) was mainly due to the growth of surviving individuals, and loss rates $\left(1.40 \%\right.$ year $\left.^{-1}\right)$ due to losses caused by the death of individuals. The higher rates of annual gain compared to loss, resulted in positive net changes in biomass with increased basal area in the tree community (tables 1, 2).

Recruitment and mortality events occurred mainly in the first two size classes (table 3); the first three diameter classes showed differences between the abundance of dead individuals and recruits when cross-compared. The first diameter class had a high number of recruits, whereas the first two size classes falling between 3 and $15 \mathrm{~cm} \mathrm{DBH}$ had the highest mortality. Of the total number of dead individuals (79 individuals), $93.7 \%$ were recorded in these first two size classes, while the trees with $\mathrm{DBH} \geq 15 \mathrm{~cm}$ accounted for only $6.3 \%$ of dead individuals (5 individuals) (table 3).
The five species of higher abundance and importance value (IV) were the same in both survey periods (figure 2) and consisted of Anadenanthera colubrina (Vell.) Brenan, Poincianella pluviosa (DC.) L.P. Queiroz, Myracrodruon urundeuva Allemão, Handroanthus ochraceus (Cham.) Mattos, and Schinopsis brasiliensis Engl. In 2005, $H$. ochraceus, P. pluviosa, and S. brasiliensis exhibited high density of small-sized individuals, which formed the lower strata under the canopy (figure 2B, C, F). The other two species, A. colubrina and M. urundeuva, exhibited high densities, however they also presented high dominances due to the presences of larger individuals (figure 2D, E).

As observed in the total sample, the most abundant tree species exhibited higher annual increment in basal area than losses due to mortality, resulting in net positive changes, especially in $H$. ochraceus and $M$. urundeuva (table 2). This accentuated the net positive changes (table 2) associated with an increase in cover value in $M$. urundeuva (table 4). The basal area gain observed in M. urundeuva accentuated its relative dominance (table 3), and as a result, the species had the second highest importance value (IV) in 2010, moving up one position from 2005.

The five important species showed more differing patterns in recruitment than in mortality: Handroanthus ochraceus was the only species which showed significantly higher recruitment than mortality events (table 2), whereas A. colubrina and S. brasiliensis showed an opposite pattern (table 2). In P. pluviosa and M. urundeuva (table 2), mortality rates were higher than recruitment, although the number of dead individuals and recruits did not differ significantly. Therefore, with the exception of $H$. ochraceus, there was an overall reduction in the number of individuals and absolute densities between surveys among the important species (table 2). 


\section{DISCUSSION}

We surveyed a Seasonally Dry Tropical Forest fragment in northern Minas Gerais in 2005 and 2010 to examine the successional dynamics of the tree community. Our study represents one of the few, to date, to examine the temporal vegetation dynamics of SDTF vegetation in Brazil (Werneck and Franceschinelli 2004). In general we found a number of changes in tree demography and vegetation dynamics patterns in line with a later successional forest.

Species richness and diversity. The species richness of the community we sampled is typical of seasonally dry Brazilian ecosystems, which ranges between 36 and 110 species per hectare (Apgaua et al. 2014a, Reis et al. 2017), and
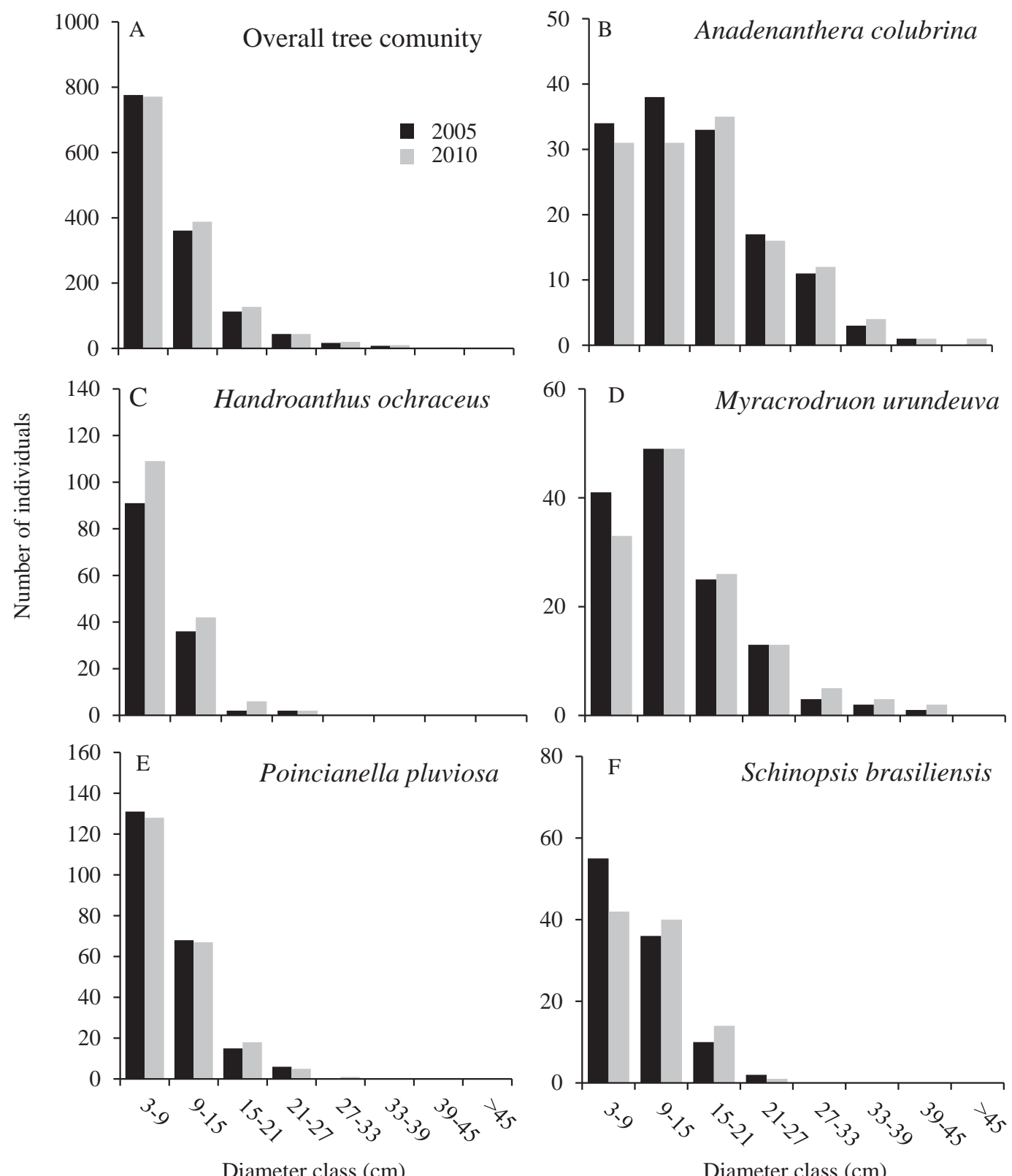

Figure 2. Number of individuals per diameter class for (A) the total sample; (B) Anadenanthera colubrina; (C) Handroanthus ochraceus; (D) Myracrodruon urundeuva; (E) Poincianella pluviosa; and (F) Schinopsis brasiliensis in a Seasonally Dry Tropical Forest tree community in Minas Gerais, southeast Brazil in 2005 and 2010.

Número de individuos por clase de diámetro para (A) la muestra total; (B) Anadenanthera colubrina; (C) Handroanthus ochraceus; (D) Myracrodruon urundeuva; (E) Poincianella pluviosa; y (F) Schinopsis brasiliensis en una comunidad de bosques tropicales estacionalmente secos en Minas Gerais, sudeste de Brasil en 2005 y 2010. 
Table 2. Dynamics parameters and abundance of dead and recruited individuals for the total sample and for the most abundant species of a seasonally dry tropical forest tree community in Minas Gerais, southeast Brazil in 2005 and 2010. The abbreviations M and R correspond to the number of dead and recruited individuals, and $\mathrm{BA}_{\mathrm{m}}$ and $\mathrm{BA}$ to the basal area $\left(\mathrm{m}^{2}\right)$ of these dead and recruited individuals respectively; $\mathrm{N}_{0}$ and $\mathrm{N}_{\mathrm{t}}$ to stem abundance, and $\mathrm{BA}, \mathrm{BA}$ to the basal areas of these individuals in the 2005 and 2010 surveys respectively; $\mathrm{TN}$ and $\Delta \mathrm{N}$ to turnover, and net changes in abundance; $\mathrm{BA}_{\mathrm{g}}$, and $\mathrm{BA}_{\mathrm{d}}$ to basal area gain and decrease respectively; $\mathrm{L}$, $\mathrm{G}$, TBA and $\triangle \mathrm{BA}$ correspond, respectively, to annual rates of basal area loss (\%), gain (\%), and turnover and net change in basal area; G-test to the G-test statistic (Zar 2010) and ns: non-significant at $\alpha=0.05$.

Parámetros de dinámica y abundancia de individuos muertos y reclutados para la muestra total y para las especies más abundantes de una comunidad de bosques tropicales estacionalmente secos en Minas Gerais, sudeste de Brasil en 2005 y 2010 . Las abreviaturas M y R corresponden al número de los individuos muertos y reclutados, y BA $\mathrm{m}_{\mathrm{m}}$ B $\mathrm{B}_{\mathrm{r}}$ al área basal $\left(\mathrm{m}^{2}\right)$ de estos individuos muertos y reclutados, respectivamente; $\mathrm{N}_{0}$ y $\mathrm{N}_{\mathrm{t}}$ para la abundancia y $\mathrm{BA}_{0}, \mathrm{BA}_{\mathrm{t}}$ a las áreas basales de estos individuos en los estudios de 2005 y 2010 , respectivamente; TN y $\Delta \mathrm{N}$ al tasa de rotación, y cambios netos en la abundancia; $\mathrm{BA}_{\mathrm{g}} \mathrm{y}_{\mathrm{BA}}$ a la ganancia y disminución del área basal, respectivamente; $\mathrm{L}, \mathrm{G}, \mathrm{TBA}$ y $\Delta \mathrm{BA}$ corresponden, respectivamente, a las tasas anuales de pérdida de área basal (\%), ganancia (\%) y tasa de rotación, y cambio neto en el área basal; prueba $\mathrm{G}$ a la pruebas estadística $\mathrm{G}$ (Zar 2010) y ns: no significativas a $\alpha=0,05$.

\begin{tabular}{|c|c|c|c|c|c|c|c|c|c|c|}
\hline & \multicolumn{4}{|c|}{ Abundance } & \multicolumn{4}{|c|}{ Dynamics parameters } & \multicolumn{2}{|c|}{ Poisson counts } \\
\hline & M & $\mathrm{R}$ & $\mathrm{N}_{0}$ & $N_{t}$ & M & $\mathrm{R}$ & $\mathrm{TN}$ & $\Delta \mathrm{N}$ & G-test & $P$ \\
\hline Total sample & 81 & 123 & 1,321 & 1,363 & 1.26 & 1.87 & 1.57 & 0.63 & 2.94 & $<0.01$ \\
\hline Anadenanthera colubrine & 8 & 1 & 137 & 130 & 1.20 & 0.15 & 0.68 & -1.04 & 2.33 & $<0.05$ \\
\hline Poincianella pluviosa & 12 & 10 & 220 & 218 & 1.12 & 0.93 & 1.03 & -0.18 & 0.43 & Ns \\
\hline Myracrodruon urundeuva & 4 & 1 & 135 & 132 & 0.60 & 0.15 & 0.38 & -0.45 & 1.34 & Ns \\
\hline Handroanthus ochraceus & 1 & 29 & 131 & 159 & 0.15 & 3.95 & 2.05 & 3.95 & 5.11 & $<0.001$ \\
\hline \multirow[t]{3}{*}{ Schinopsis brasiliensis } & 7 & 1 & 103 & 97 & 1.40 & 0.21 & 0.80 & -1.19 & 2.12 & $<0.05$ \\
\hline & \multicolumn{6}{|c|}{ Basal area } & \multicolumn{4}{|c|}{ Dynamics parameters } \\
\hline & $\mathrm{BA}_{\mathrm{m}}$ & $\mathrm{BA}_{\mathrm{r}}$ & $\mathrm{BA}_{0}$ & $\mathrm{BA}_{\mathrm{t}}$ & $\mathrm{BA}_{\mathrm{g}}$ & $\mathrm{BA}_{\mathrm{d}}$ & $\mathrm{L}$ & G & TBA & $\Delta \mathrm{BA}$ \\
\hline Total sample & 0.53 & 0.21 & 13.20 & 14.91 & 2.41 & 0.37 & 1.40 & 3.79 & 2.59 & 2.42 \\
\hline Anadenanthera colubrina & 0.13 & 0.002 & 3.39 & 3.67 & 0.48 & 0.04 & 1.01 & 2.81 & 1.91 & 1.62 \\
\hline Poincianella pluviosa & 0.07 & 0.01 & 1.68 & 1.77 & 0.20 & 0.05 & 1.53 & 2.51 & 2.02 & 1.01 \\
\hline Myracrodruon urundeuva & 0.04 & 0.001 & 2.64 & 3.01 & 0.43 & 0.02 & 0.46 & 3.07 & 1.77 & 2.69 \\
\hline Handroanthus ochraceus & 0.0009 & 0.05 & 0.71 & 0.96 & 0.21 & 0.0007 & 0.05 & 5.93 & 2.99 & 6.25 \\
\hline Schinopsis brasiliensis & 0.02 & 0.0008 & 0.90 & 0.95 & 0.11 & 0.04 & 1.39 & 2.43 & 1.91 & 1.07 \\
\hline
\end{tabular}

Table 3. The number of remaining, recruited and dead individuals per diameter class between 2005 and 2010 in a seasonally dry tropical forest tree community in Minas Gerais, southeast Brazil.

Número de individuos remanentes, reclutados y muertos por clase de diámetro entre 2005 y 2010 en una comunidad de bosques tropicales estacionalmente secos en Minas Gerais, sudeste de Brasil.

\begin{tabular}{lccc}
\hline Size classes $(\mathrm{cm})$ & Individuals remaining & Recruitment & Mortality \\
\hline $3-9$ & 632 & 121 & 59 \\
$9-15$ & 298 & 85 & 15 \\
$15-21$ & 92 & 33 & 2 \\
$21-27$ & 30 & 13 & 3 \\
$27-33$ & 11 & 9 & 0 \\
$33-39$ & 5 & 5 & 0 \\
$39-45$ & 1 & 1 & 0 \\
$>45$ & 1 & 1 & 0 \\
\hline
\end{tabular}


Table 4. Density, dominance and cover values for the most abundant tree species in a seasonally dry tropical forest tree community in Minas Gerais, southeast Brazil in 2005 and 2010. Absolute values of density and dominance refer to the number of stems and basal areas $\left(\mathrm{m}^{2}\right)$ respectively, and the relative values to the percentages of these values as a function of the total. Cover values are expressed as a percentage of the total cover.

Valores de densidad, dominancia y cobertura de las especies de árboles más abundantes en una comunidad de bosques tropicales estacionalmente secos en Minas Gerais, sudeste de Brasil en 2005 y 2010. Los valores absolutos de densidad y dominancia se refieren al número de tallos y áreas basales $\left(\mathrm{m}^{2}\right)$ respectivamente, y los valores relativos a los porcentajes de estos valores en función del total. Los valores de la cobertura se expresan como un porcentaje de la cobertura total.

\begin{tabular}{|c|c|c|c|c|c|c|c|c|c|c|}
\hline \multirow{3}{*}{ Species } & \multicolumn{4}{|c|}{ Density } & \multicolumn{4}{|c|}{ Dominance } & \multirow{2}{*}{\multicolumn{2}{|c|}{ Cover value }} \\
\hline & \multicolumn{2}{|c|}{ Absolute } & \multicolumn{2}{|c|}{ Relative } & \multicolumn{2}{|c|}{ Absolute } & \multicolumn{2}{|c|}{ Relative } & & \\
\hline & 2005 & 2010 & 2005 & 2010 & 2005 & 2010 & 2005 & 2010 & 2005 & 2010 \\
\hline Anadenanthera colubrina & 171.25 & 162.5 & 10.37 & 9.54 & 4.18 & 4.59 & 25.36 & 24.61 & 17.86 & 17.07 \\
\hline Poincianella pluviosa & 275 & 272.5 & 16.65 & 15.99 & 2.1 & 2.21 & 12.75 & 11.87 & 14.7 & 13.93 \\
\hline Myracrodruon urundeuva & 168.75 & 165 & 10.22 & 9.68 & 3.26 & 3.77 & 19.77 & 20.21 & 14.99 & 14.95 \\
\hline Handroanthus ochraceus & 163.75 & 198.75 & 9.92 & 11.67 & 0.89 & 1.21 & 5.4 & 6.47 & 7.66 & 9.07 \\
\hline Schinopsis brasiliensis & 128.75 & 121.25 & 7.8 & 7.12 & 1.12 & 1.18 & 6.81 & 6.36 & 7.3 & 6.74 \\
\hline
\end{tabular}

we found no significant changes in species richness and diversity between the two survey periods.

The lack of change in species richness and diversity was not surprising considering that species recovery can often occur on the scale of centuries (Chazdon 2003), and that our plots were only recensused after five years. Nevertheless, the lack of differences in species richness and diversity and evenness between surveys probably reflects that the SDTF vegetation at the study site is not at an early successional phase, although the short time period between surveys could have made it less likely that new species were recruited.

Tree demography and population dynamics. Contrary to our hypothesis that there would be a reduction in stem density, we found a small increase in stem abundance after five years. This slight change was again probably due to the short time period between surveys; nevertheless, the slight increase is much lower than what would be expected for an early successional forest. Similar findings have been reported for mature Amazonian and Atlantic forests (Lewis et al. 2004, Saiter et al. 2011) because tree population dynamics in late successional forests is characterized by slow growth and recruitment rates, and thus low turnover rates (Swaine and Whitmore 1988). In deciduous and ombrophilous forests subjected to more frequent anthropogenic and natural disturbances, other works have found a higher turnover in abundance (Lewis et al. 2004, Werneck and Franceschinelli 2004, Fontes and Walter 2011).

The tree community in our study exhibited a low mortality rate compared to riparian rain forests (Guilherme et al. 2004, Fontes and Walter 2011), and also some seasonal tropical forests (Werneck and Franceschinelli 2004), which was contrary to our expectations considering that seasonal drought may be a cause of high mortality in SDTFs. However, more data will be needed to validate this point.

In terms of basal area, the tree basal area turnover rates of the tree community in our study were high, considering that rates above $2 \%$ have been reported in more dynamic, seasonal forest fragments often subjected to natural disturbances (Guilherme et al. 2004) or with recent natural regeneration (Machado and Oliveira-Filho 2010). Lewis et al. (2004) reported high basal area turnover rates in Amazonian moist forests at late successional stages and showed that mature forests may have accelerated biomass dynamics. Likewise, the high turnover rate in basal area in our study was mainly due to the high basal area gain, which appears to be related to the high percentage of surviving individuals and their increase in basal area. In particular, this is a result of the increment of larger diameter trees. The basal area gain of recruits represented only $12.2 \%$ of total basal area increment, which is slightly lower than the value observed in more humid tropical rain forests, where recruits may represent on average $15 \%$ of the basal area increment (Lewis et al. 2004).

In terms of demography and diameter size class distributions, tree populations in tropical rain forests often exhibit a reverse J-shaped diameter size class curve (Sheil and May 1996), due to continuous recruitment and gapphase dynamics favoring a large number of stems in the smallest size classes. Likewise, our tree size class distributions show that the overall tree community and some of the most abundant species exhibit a similar reverse J-shaped diameter size class curve, perhaps reflecting continuous recruitment during wet seasons. However, we also found that in a number of key species (A. colubrina, $\mathrm{H}$. ochraceus and $M$. urundeuva), the largest number of individuals 
was concentrated in the second DBH size class $(9-15 \mathrm{~cm})$. The absence of a typical reverse J-shaped diameter curve in these species has been reported in other similar sites (Apgaua et al. 2014a), and may reflect an inherent difference in the demography of humid forest and some seasonal forest tree populations. It is also possible that past human use may have played a role in these patterns, although this needs to be further validated.

The occurrence of seasonal drought in SDTF habitats is possibly the key driver of differences in these demographic and dynamic patterns. For some species, the lower abundance of trees in the first, compared to the second diameter class at our site, may reflect the strategies of lower size classes in response to seasonal water shortage, which is more likely to lead to mortality in younger individuals (Fauset et al. 2012). Particularly in areas with seasonally dry soils, the shallow root systems of smaller-sized plants may limit their ability to tap into deeper soil water reservoirs. Individuals and species that can grow fast during favorable periods would therefore have a chance of survival, and therefore move into a larger size class.

Demography of important species. Our five important species, Anadenanthera colubrina, Handroanthus ochraceus, Myracrodruon urundeuva, Poincianella pluviosa and Schinopsis brasiliensis, represent the most frequent and abundant species that characterize Seasonally Dry Tropical Forests in northern Minas Gerais (Santos et al. 2012) and in Brazil in general (Särkinen et al. 2011), and can, therefore, provide important insights in the long-term dynamics of SDTFs.

The patterns of change in the demography of these species reflect the changes in community structure and species hierarchy of the tree community, highlighting the dynamic equilibrium of tropical forests. For instance, the reduction in density of A. colubrina, P. pluviosa, S. brasiliensis and M. urundeuva (accompanied by a reduction in dominance in the first three species) was probably associated with an increase in density or dominance of other species, although there was very little or no change in the overall diversity or evenness in the community across survey periods. Moreover, the increment in abundance and basal area of $H$. ochraceus and the increased dominance of M. urundeuva, which are representative of the subcanopy and canopy respectively, reflect an increased vertical complexity in the tree community. This increase in abundance and basal area of $H$. ochraceus and the biomass accumulation of M. urundeuva may represent the recovery of these tree populations from exploitation since the area was demarcated for protection.

\section{CONCLUSIONS}

After a five-year period between surveys in a remnant patch of seasonally dry tropical forest, we found no significant differences in species richness and diversity. In addi- tion, the patterns of evenness and natural regeneration that we found during our 5-year study period suggest that our tree community is at a late successional stage, although continuous monitoring over longer time periods would be needed to validate this point further. In general, we observed a high proportion of stems at the smallest stem size classes of our tree community due to high recruitment; nevertheless, at the same time, this class of small-stemmed individuals also exhibited high mortality. This demographic pattern reflects stable vegetation dynamics in agreement with previous studies. Our study fills a knowledge gap on temporal studies in seasonally dry tropical forest, and will have implications for the conservation and management of seasonally dry forests in the region. Future studies may benefit from modelling the demography of important seasonally dry tropical forest species across a wider geographical extent.

\section{ACKNOWLEDGEMENTS}

The work was supported by funding from Coordenação de Aperfeiçoamento de Pessoal de Nível Superior (CAPES), Conselho Nacional de Desenvolvimento Cientifico e Tecnológico $(\mathrm{CNPq})$ and Fundação de Amparo à Pesquisa de Minas Gerais (FAPEMIG). David Tng was supported by an Endeavour Postdoctoral Research Fellowship from the Endeavour foundation. Deborah Apgaua was supported by a Postdoctoral Research Fellowship from the Schlumberger foundation. We thank Lain Pardo for help with Spanish.

\section{REFERENCES}

Apgaua DMG, PA Coelho, RMD Santos, PF Santos, AT OliveiraFilho. 2014a. Tree community structure in a seasonally dry tropical forest remnant, Brazil. Cerne 20(2): 173-182.

Apgaua DMG, RM Santos, DGS Pereira, GC Menino, GG Pires, MA Fontes, DY Tng. 2014b. Beta-diversity in seasonally dry tropical forests (SDTF) in the Caatinga Biogeographic Domain, Brazil, and its implications for conservation. Biodiversity and Conservation 23(1): 217-232.

Coelho PA, PF Santos, EP Paiva, DMG Apgaua, BG Madeira, GCO Menino, YRF Nunes, RM Santos, DYP Tng. 2016. Tree succession across a Seasonally Dry Tropical Forest and forest-savanna ecotone in northern Minas Gerais, Brazil. Journal of Plant Ecology 10(5): 859-868. DOI: 10.1093/jpe/rtw091.

Colwell RK. EstimateS: statistical estimation of species richness and shared species from samples, version 9.1.0. Consulted 08 Jun. 2017. Available in http://purl.oclc.org/estimates. 2013.

Chazdon RL. 2003. Tropical forest recovery: legacies of human impact and natural disturbances. Perspectives in plant ecology, Evolution and Systematics 6(1-2): 51-71.

de Albuquerque UP, EL Araújo, ACA El-Deir, ALA de Lima, A Souto, BM Bezerra, EMN Ferraz, EMX Freire, EVDSB Sampaio, FMG Las-Casas, GJBD Moura, GA Pereira, JGD Melo, MA Ramos, MJN Rodal, N Schiel, RMD Lyra-Ne- 
ves, RRN Alves, SMD Azevedo-Junior, WR Telino Junior, W Severi. 2012. Caatinga revisited: ecology and conservation of an important seasonal dry forest. The Scientific World Journal. DOI: 10.1100/2012/205182.

Fauset S, TR Baker, SL Lewis, TR Feldpausch, K Affum-Baffoe, EG Foli, KC Hamer, MD Swaine. 2012. Drought-induced shifts in the floristic and functional composition of tropical forests in Ghana. Ecology Letters 15(10): 1120-1129.

Fontes CG, BMT Walter. 2011. Dinâmica do componente arbóreo de uma mata de galeria inundável (Brasília, Distrito Federal) em um período de oito anos. Acta Botanica Brasilica 34(2): 145-158.

Guilherme FAG, AT Oliveira-Filho, V Appolinário, E Bearzoti. 2004. Effects of flooding regimes and woody bamboos on tree community dynamics in a section of tropical semideciduous forest in South-Eastern Brazil. Plant Ecology 174(1): 19-36.

Kent M. 2011. Vegetation description and data analysis: a practical approach. Chichester, England. John Wiley. 428 p.

Korning J, H Balslev. 1994. Growth and mortality of trees in Amazonian tropical rain forest in Ecuador. Journal of Vegetation Science 5(1): 77-86.

Lebrija-Trejos E, JA Meave, L Poorter, EA Pérez-García, F Bongers. 2010. Pathways, mechanisms and predictability of vegetation change during tropical dry forest succession. Perspectives in Plant Ecology, Evolution and Systematics 12(4): 267-275.

Lewis SL, OL Phillips, TR Baker, J Lloyd, Y Malhi, S Almeida, N Higuchi, WF Laurance, DA Neill, JN Silva, J Terborgh. 2004. Concerted changes in tropical forest structure and dynamics: evidence from 50 South American long-term plots. Philosophical Transactions of the Royal Society B: Biological Sciences 359(1443): 421-436.

Lieberman D, M Lieberman, R Peralta, GS Hartshorn. 1985. Mortality patterns and stand turnover rates in a wet tropical forest in Costa Rica. Journal of Tropical Ecology 73(3): 915-924.

Machado ELM, AT Oliveira-Filho. 2010. Spatial patterns of tree community dynamics are detectable in a small (4 ha) and disturbed fragment of the Brazilian Atlantic forest. Acta Botanica Brasilica 24(1): 250-261.

Marín GC, R Nygard, BG Rivas, PC Oden. 2005. Stand dynamics and basal area change in a tropical dry forest reserve in Nicaragua. Forest Ecology and Management 208(1-3): 63-75.

Reis GH, MDCNS Terra, DYP Tng, DMG Apgaua, PA Apgaua, RM Santos, YRF Nunes. 2017. Temporal vegetation changes in a seasonally dry tropical forest enclave in an ecotonal region between savanna and semiarid zones of Brazil. Australian Journal of Botany 65(1): 85-93.

Saiter FZ, FAG Guilherme, LD Thomaz, T Wendt. 2011. Tree changes in a mature rainforest with high diversity and endemism on the Brazilian coast. Biodiversity and Conservation 20(9): 1921-1949.

Santos RM, ACMC Barbosa, HS Almeida, FA Vieira, PF Santos, DA Carvalho, AT Oliveira-Filho. 2011. Estrutura e florística de um remanescente de caatinga arbórea em Juvenília, norte de Minas Gerais, Brasil. Cerne 17(2): 247-258.

Santos RM, AT Oliveira-Filho, PV Eisenlohr, LP Queiroz, DB Cardoso, MJ Rodal. 2012. Identity and relationships of the Arboreal Caatinga among other floristic units of seasonally dry tropical forests (SDTFs) of north-eastern and Central Brazil. Ecology and Evolution 2(2): 409-428.

Särkinen T, JR Iganci, R Linares-Palomino, MF Simon, DE Prado. 2011. Forgotten forests-issues and prospects in biome mapping using Seasonally Dry Tropical Forests as a case study. BMC Ecology 11:27 DOI: 10.1186/1472-6785-11-27.

Sheil D, M May. 1996. Mortality and recruitment rate evaluations in heterogeneous tropical forests. Ecology 84(1): 91-100.

Swaine MD, TC Whitmore. 1988. On the definition of ecological species groups in tropical rain forests. Vegetatio 75(1): 81-86.

Werneck MS, EV Franceschinelli. 2004. Dynamics of a dry forest fragment after the exclusion of human disturbance in southeastern Brazil. Plant Ecology 174(2): 339-348.

Zar JH. 2010. Biostatistical Analysis. Upper Saddle River, New Jersey, USA. Prentice-Hall. 944 p.

Recibido: 09.06.17

Aceptado: 11.09.17 
